\title{
Skirtingomis epilepsijos formomis sergančių asmenų miego ir gydymo režimo laikymosi drausmingumo vertinimas
}

\section{Streckytė* \\ R. Mameniškienė** \\ *Vilniaus universiteto \\ Medicinos fakultetas \\ **Vilniaus universitetas, \\ Neurologijos centras}

\begin{abstract}
Santrauka. İvadas. Ilgalaikis gydymas vaistais nuo epilepsijos maždaug $70 \%$ asmenų, sergančių epilepsija, padeda pasiekti, kad priepuoliai nesikartotų, tačiau nedrausmingas vaistụ vartojimas - pagrindinė gydymo nesėkmès priežastis.

Darbo tikslas. Nustatyti, ar skirtingomis epilepsijos formomis sergantys asmenys drausmingai laikosi miego ir gydymo režimo, ir ịvertinti tai lemiančius veiksnius.

Tyrimo metodai. Vilniaus universiteto ligoninès Santaros klinikose vykdyta suaugusių ir vaistus nuo epilepsijos vartojančių epilepsija sergančių asmenų anoniminė anketinė apklausa. Duomenys apdoroti „MS Excel“ ir SPSS 21.0 programomis. Duomenys laikyti statistiškai reikšmingais, kai $\mathrm{p}<0,05$.

Rezultatai. Tyrime dalyvavo 100 epilepsija segančių asmenų (65 \% - sergančiujų židinine epilepsija, $55 \%$ - moterų). Tiriamujų amžiaus mediana - 37,5 $\pm 15,7$ metų, vidutinè ligos trukmè $-9,5 \pm 11$ metų, vidutinis susirgimo epilepsija amžius $-21,5 \pm 17$ metų. Vaistus nuo epilepsijos nedrausmingai vartoja $30 \%$ epilepsija sergančių asmenų, nepriklausomai nuo epilepsijos formos $(\mathrm{p}=0,819)$, dažniausia priežastis - užmaršumas $(82,4 \%)$. Nedrausmingas vaistu vartojimas yra statistiškai reikšmingai susijęs su gyvenamaja vieta (kaime; $\mathrm{p}=0,032)$; dažnais priepuoliais $(\mathrm{p}=0,033)$; retesniu vaistų nuo epilepsijos dozavimu $(p=0,032)$, dažniau sergančiujų generalizuota epilepsija grupejje $(p=0,019)$. Miego režimas nuo epilepsijos formos nepriklauso $(\mathrm{p}>0,05), 35 \%$ respondentų naktị miega mažiau nei 7 valandas, $53 \%$ respondentų nesilaiko miego režimo ir tai yra susiję su nedrausmingu vaistų vartojimu $(\mathrm{p}=0,027)$.

Išvados. Vaistų nuo epilepsijos vartojimo ir miego režimo laikymosi drausmingumas nuo epilepsijos formos nepriklauso. Kas trečias epilepsija sergantis asmuo vaistus vartoja nedrausmingai. Dažniausia subjektyvi gydymo režimo nesilaikymo priežastis - užmaršumas, o objektyvios: gyvenimas kaimo vietovẻje, dažni priepuoliai ir retesnės vaistų dozės. Trečdalis respondentų miega mažiau nei rekomenduojama, daugiau nei pusè - nesilaiko reguliaraus miego režimo. Nesilaikantys miego režimo linkę gydytis nedrausmingai.
\end{abstract}

Raktažodžiai: drausmingumas, epilepsija, miegas, režimas, vaistai nuo epilepsijos.

\section{IVADAS}

Epilepsija yra viena labiausiai paplitusių lètinių neurologinių ligų, kuria pasaulyje serga daugiau kaip 50 milijonų gyventojų [1]. Tai sekinanti liga, kuri sukelia neuropsicho-

\section{Adresas:}

Dovile Streckytė

Vilniaus universiteto Medicinos fakultetas

M. K. Čiurlionio g. 21, LT-03101 Vilnius

El. paštasdstreckyte@gmail.com loginius sutrikimus, blogina gyvenimo kokybę, didina socialinę atskirtị, lemia prastus mokymosi rezultatus, fizinius susižalojimus ir trumpesnę gyvenimo trukmę [2-4]. Pagrindinė epilepsijos gydymo priemonė - ilgalaikis (kasdien ir dažnai visą gyvenimą) vaistų nuo epilepsijos (VNE) vartojimas, kurio tikslas - pasiekti, kad priepuoliai nesikartotų (tai pavyksta maždaug $70 \%$ pacientų) ar bent jau taptų lengvesni, trumpesni ir retesni [5-8]. Norint veiksmingai valdyti ligą, būtina laikytis teisingo gyvenimo būdo ir griežto VNE vartojimo režimo [6]. Kadangi epilepsijai yra būdingi trumpalaikiai simptomai ir požymiai (t. y.

(C) Neurologijos seminarai, 2020. Open Access. This article is distributed under the terms of the Creative Commons Attribution 4.0 International License CC-BY 4.0 (http://creativecommons.org/licenses/by/4.0/), which permits unrestricted use, distribution, and reproduction in any medium, provided you give appropriate credit to the original author(s) and the source, provide a link to the Creative Commons license, and indicate if changes were made. 
priepuoliai), o ne nuolat jaučiamas reiškinys (pvz., skausmas), pacientas privalo vartoti vaistus, nejausdamas greito ir akivaizdaus teigiamo poveikio. Taigi pacientai, praleidę vaistų dozes be neigiamo poveikio sveikatai, gali klaidingai galvoti, kad nèra svarbu griežtai laikytis vaistų vartojimo režimo [6, 7]. Kitiems dažniausiems veiksniams, susijusiems su VNE nevartojimu, priskiriami: žemas sociodemografinis statusas [9], žemesnis išsilavinimas [9-11], priklausymas etninei mažumai [11], jaunesnis amžius [9, 12], rūkymas ir kiti žalingi ịpročiai [13], užmaršumas [8, $14,15]$, ìsitikinimas apie neigiamą VNE poveiki $[11,14]$, ilgesnè ligos ir gydymo trukmè [16, 17], didelis vartojamų vaistų skaičius $[11,15,18]$, jų sukeliamos nepageidaujamos reakcijos [8, 14, 15, 18], sveikatos būklès pagerèjimas $[8,14,15]$, priepuolių nebuvimas $[9,14]$, gretutinès patologijos (pvz., depresija) $[9,11]$ ir stigmatizacija $[8,9,11$, 18]. Dar vienas svarbus prastesnès epilepsijos kontrolès veiksnys - miego režimo nesilaikymas. Miego trūkumas gali sukelti priepuolių pasikartojimą, kurie blogina miego kokybę, trikdo kasdienę veiklą. Dèl to neretai epilepsija sergantys asmenys (ESA) skundžiasi padidèjusiu mieguistumu dieną, nemiga ar sutrikusia miego kokybe [19]. Visgi gydymo režimo nesilaikymas išlieka pagrindine nesèkmingo epilepsijos gydymo priežastimi [20,21]. Nepaisant veiksmingų vaistų prieinamumo, ESA dažnai nesilaiko gydytojo nurodyto gydymo režimo - praleidžia VNE dozes, nevartoja vaistų arba geria juos mažesne doze ar kitu laiku nei nurodyta, savarankiškai koreguoja jų vartojimą būklei pagerejjus ar atsiradus nepageidaujamų reakcijų [22]. Todėl mažèja gydymo efektyvumas, vystosi farmakologinis atsparumas, dideja priepuolių pasikartojimo, lūžių, galvos traumų ir mirštamumo rizika, auga hospitalizacijų skaičius, sveikatos priežiūros išlaidos, blogèja gyvenimo kokybė $[6,11,20,22,23]$. Ankstesni tyrimai atskleidé, kad pacientų, nesilaikančių rekomenduoto gydymo, mirštamumo rizika yra net tris kartus didesne, palyginus su asmenimis, drausmingai vartojančiais VNE [22, 24]. Ivairių tyrimų duomenimis, VNE nedrausmingo vartojimo dažnis (vaistų vartojimo nutraukimas, dozių sumažinimas ir pan.) tarp sergančių įvairiomis epilepsijos formomis svyruoja nuo 21 iki $79 \%$ [8, 10, 18, 21, 25-27]. Tokị didelị rezultatų skirtumą lemia tai, kad kliniškai reikšmingas vaistų vartojimo nedrausmingumas vertinamas naudojant skirtingas metodikas (anketos, vaistų koncentracijos kraujo serume tyrimas ir pan.), jam apibrèžti iki šiol nèra bendro susitarimo [9].

\section{DARBO TIKSLAS}

Pagrindinis tikslas: nustatyti skirtingomis epilepsijos formomis sergančių pacientų miego ir gydymo režimo laikymosi drausmingumą ir įvertinti tai lemiančius veiksnius bei jų ịtaką epilepsijos priepuolių kontrolei.

\section{Uždaviniai:}

1) Nustatyti nedrausmingo VNE vartojimo dažnį sergančiųjų židinine epilepsija (ŽE) ir generalizuota epilepsija (GE) grupèse.
2) Nustatyti dažniausias pacientų VNE nevartojimo priežastis ir jų priklausomybę nuo epilepsijos formos.

3) İvertinti sergančiųjų ŽE ir GE nuomonę apie VNE.

4) İvertinti nuomonès apie VNE ir VNE vartojimo drausmingumo tarpusavio ryši.

5) İvertinti asmenų, sergančių ŽE ir GE, miego režimą.

6) Icvertinti miego režimo ir VNE vartojimo drausmingumo tarpusavio ryši.

\section{TIRIAMIEJI IR METODAI}

\section{Tiriamieji}

Tyrimas atliktas Vilniaus universiteto ligoninès Santaros klinikų (VUL SK) Epilepsijos ir miego sutrikimų kabinete 2019 m. lapkričio - 2020 m. vasario mènesị. Itraukimo ị tyrimą kriterijai: 18 metų ir vyresni epilepsija sergantys pacientai, vartojantys VNE, suprantantys ir gebantys atsakyti į anketoje pateiktus klausimus ir sutinkantys dalyvauti apklausoje. I tyrimą neictraukti VNE nevartojantys asmenys, nesutinkantys dalyvauti apklausoje ir nesugebantys atsakyti i klausimus (nesuprantantys lietuviškai, turintys sąmonės, suvokimo sutrikimų, protinę negalią ir kt.).

\section{Metodika}

Tyrimui atlikti gautas Vilniaus universiteto ligoninès Santaros kliniku Etikos komiteto leidimas (Nr. GR-5755). Atliktas pjūvinis analitinis tyrimas, kurio metu naudota tyrejjų naujai sukurta anoniminė anketa, sudaryta iš 45 uždaro tipo klausimų: 7 klausimai apie sociodemografinius duomenis, 13 bendrų klausimų apie epilepsiją ir sveikatos būklę, 10 klausimų apie VNE vartojimo drausmingumą, 3 klausimai apie sunkumus (jų dažnį), patiriamus laikantis paskirto gydymo plano, 7 klausimai apie VNE ir jų poveikį sveikatos būklei ir 5 klausimai apie miego režimą.

Nedrausmingu paskirtu VNE vartojimu laikyta, kai respondentas bent ị du iš pateiktų šešių klausimų atsakẻ teigiamai. Vertinti šie klausimai: 1) ar kada nors esate pamiršę išgerti vaistus nuo epilepsijos; 2) ar kada nors esate vartoję vaistus nuo epilepsijos, nesilaikydami nurodyto gydymo režimo; 3) ar kartais nevartojate vaistų nuo epilepsijos, nes jaučiate sveikatos būklès pagerẻjimą; 4) ar esate savarankiškai sumažinę vaisto dozę, kai priepuolių dažnis sumažèjo; 5) ar esate savarankiškai nutraukę vaistų vartojimą, kai jautėtès blogiau, 6) ar atsirado šalutinių reiškinių, vartojant vaistus.

\section{Duomenų apdorojimas}

Statistinè duomenų analizè atlikta naudojant „Microsoft Office Excel 2010“ ir IBM SPSS 21.0 programinius paketus. Duomenims apdoroti naudota aprašomoji statistika - vidurkiams, standartiniams nuokrypiams apskaičiuoti. Kiekybiniai kintamieji pateikiami vidurkiu ar me- 
1 lentelè. Tiriamųjų demografiniai ir klinikiniai duomenys

\begin{tabular}{|c|c|c|c|c|c|}
\hline \multicolumn{2}{|c|}{ Demografiniai ir klinikiniai duomenys } & $\begin{array}{c}\text { Visi pacientai, } \\
\text { N }(\%)\end{array}$ & $\begin{array}{c}\text { Sergantieji } \check{Z} E, \\
\text { N (\%) }\end{array}$ & \begin{tabular}{|c|} 
Sergantieji GE, \\
$\mathbf{N}(\%)$
\end{tabular} & p reikšmè* \\
\hline \multicolumn{2}{|c|}{ Amžius (mediana $\pm \mathrm{SN}$, metais) } & $37,5 \pm 15,7(18-83)$ & $39 \pm 15,6(18-83)$ & $29 \pm 15(18-72)$ & $p=0,038^{3}$ \\
\hline \multirow[t]{2}{*}{ Lytis } & Vyras & $45(45 \%)$ & $35(53,9 \%)$ & $10(28,6 \%)$ & \multirow[t]{2}{*}{$p=0,015^{1}$} \\
\hline & Moteris & $55(55 \%)$ & $30(46,1 \%)$ & $25(71,4 \%)$ & \\
\hline \multirow[t]{5}{*}{ Gyvenimo sąlygos } & Gyvena vienas & $13(13 \%)$ & $7(10,8 \%)$ & $6(17,1 \%)$ & \multirow[t]{5}{*}{$\mathrm{p}=0,298^{1}$} \\
\hline & Gyvena su partneriu (-e) & $38(38 \%)$ & $29(44,6 \%)$ & $9(25,7 \%)$ & \\
\hline & Gyvena su vaikais & $11(11 \%)$ & $8(12,3 \%)$ & $3(8,6 \%)$ & \\
\hline & Gyvena su tėvais & $21(21 \%)$ & $11(16,9 \%)$ & $10(28,6 \%)$ & \\
\hline & Gyvena su šeima & $17(17 \%)$ & $10(15,4 \%)$ & $7(20 \%)$ & \\
\hline \multirow[t]{4}{*}{ Išsilavinimas } & Pradinis & $5(5 \%)$ & $3(4,6 \%)$ & $2(5,7 \%)$ & \multirow{4}{*}{$\mathrm{p}=0,974^{1}$} \\
\hline & Vidurinis & $40(40 \%)$ & $26(40 \%)$ & $14(40 \%)$ & \\
\hline & Nebaigtas aukštasis & $10(10 \%)$ & $6(9,2 \%)$ & $4(11,4 \%)$ & \\
\hline & Aukštasis & $45(45 \%)$ & $30(46,2 \%)$ & $15(42,9 \%)$ & \\
\hline \multirow[t]{5}{*}{ Užimtumas } & Dirba & $53(53 \%)$ & $33(50,8 \%)$ & $20(57,2 \%)$ & \multirow[t]{5}{*}{$p=0,046^{1}$} \\
\hline & Mokosi & $5(5 \%)$ & $1(1,5 \%)$ & $4(11,4 \%)$ & \\
\hline & Studijuoja & $7(7 \%)$ & $3(4,6 \%)$ & $4(11,4 \%)$ & \\
\hline & Bedarbis & $22(22 \%)$ & $18(27,7 \%)$ & $4(11,4 \%)$ & \\
\hline & Pensininkas & $13(13 \%)$ & $10(15,4 \%)$ & $3(8,6 \%)$ & \\
\hline \multirow[t]{2}{*}{ Gyvenamoji vieta } & Miestas & $85(85 \%)$ & $55(84,6 \%)$ & $30(85,7 \%)$ & \multirow[t]{2}{*}{$\mathrm{p}=0,883^{1}$} \\
\hline & Kaimas & $15(15 \%)$ & $10(15,4 \%)$ & $5(14,3 \%)$ & \\
\hline \multirow[t]{2}{*}{ Žalingi ịpročiai } & Rūko & $20(20 \%)$ & $14(21,5 \%)$ & $6(17,1 \%)$ & \multirow[t]{2}{*}{$\mathrm{p}=0,599^{2}$} \\
\hline & Vartoja alkoholi & $7(7 \%)$ & $5(7,7 \%)$ & $2(5,7 \%)$ & \\
\hline \multicolumn{2}{|c|}{ Ligos trukmė (mediana $\pm \mathrm{SN}$, metais) } & $9,5 \pm 11$ & $8 \pm 9,5$ & $15 \pm 14,4$ & $p=0,045^{3}$ \\
\hline \multicolumn{2}{|c|}{ Susirgimo epilepsija amžius (mediana $\pm \mathrm{SN}$, metais) } & $21,5 \pm 17$ & $29 \pm 17,8$ & $17 \pm 11,3$ & $p=0,000^{3}$ \\
\hline \multirow[t]{3}{*}{ VNE skaičius } & $1 \mathrm{VNE}$ & $54(54 \%)$ & $36(55,4 \%)$ & $18(51,4 \%)$ & \multirow[t]{3}{*}{$\mathrm{p}=0,227^{1}$} \\
\hline & $2 \mathrm{VNE}$ & $28(28 \%)$ & $15(23,1 \%)$ & $13(37,2 \%)$ & \\
\hline & $\geq 3 \mathrm{VNE}$ & $18(18 \%)$ & $14(21,5 \%)$ & $4(11,4 \%)$ & \\
\hline \multirow{2}{*}{$\begin{array}{l}\text { Priepuoliai } \\
\text { kontroliuojami }\end{array}$} & Taip & $76(76 \%)$ & $48(73,9 \%)$ & $28(80 \%)$ & \multirow[t]{2}{*}{$\mathrm{p}=0,492^{1}$} \\
\hline & $\mathrm{Ne}$ & $24(24 \%)$ & $17(26,1 \%)$ & $7(20 \%)$ & \\
\hline \multirow[t]{4}{*}{ Priepuolių dažnumas } & Kasdien & $6(6 \%)$ & $5(7,7 \%)$ & $1(2,9 \%)$ & \multirow[t]{4}{*}{$\mathrm{p}=0,220^{1}$} \\
\hline & Kelis kartus per mėnesi & $24(24 \%)$ & $18(27,7 \%)$ & $6(17,1 \%)$ & \\
\hline & Kelis kartus per metus & $34(34 \%)$ & $23(35,4 \%)$ & $11(31,4 \%)$ & \\
\hline & $\geq 1$ metus priepuolių nebuvo & $36(36 \%)$ & $19(29,2 \%)$ & $17(48,6 \%)$ & \\
\hline \multirow[t]{2}{*}{ Gydymo VNE trukmé } & $<5$ metus & $41(41 \%)$ & $24(36,9 \%)$ & $17(48,6 \%)$ & $\mathrm{p}=0,259^{1}$ \\
\hline & $>5$ metus & $59(59 \%)$ & $41(63,1 \%)$ & $18(51,4 \%)$ & \\
\hline VNE dozių skaičius per & 1 & $8(8 \%)$ & $3(4,6 \%)$ & $5(14,3 \%)$ & $\mathrm{p}=0,241^{1}$ \\
\hline dieną & 2 & $76(76 \%)$ & $53(81,6 \%)$ & $28(80 \%)$ & \\
\hline & 3 & $10(10 \%)$ & $8(12,3 \%)$ & $2(5,7 \%)$ & \\
\hline & $>3$ & $1(1 \%)$ & $1(1,5 \%)$ & $0(0 \%)$ & \\
\hline Visų vartojamų vaistų & 1 & $40(40 \%)$ & $26(40 \%)$ & $14(40 \%)$ & $p=0,230^{1}$ \\
\hline skaičius & $2-5$ & $55(55 \%)$ & $34(52,3 \%)$ & $21(60 \%)$ & \\
\hline & $>5$ & $5(5 \%)$ & $5(7,7 \%)$ & $0(0 \%)$ & \\
\hline VNE sukelti nepageidau- & Taip & $33(33 \%)$ & $23(35,4 \%)$ & $10(28,6 \%)$ & $\mathrm{p}=0,489^{1}$ \\
\hline jami reiškiniai & $\mathrm{Ne}$ & $67(67 \%)$ & $42(64,6 \%)$ & $25(71,4 \%)$ & \\
\hline Subjektyvus sveikatos & Gera & $38(38 \%)$ & $23(35,4 \%)$ & $15(42,9 \%)$ & $p=0,427^{1}$ \\
\hline būklès vertinimas & Vidutiniška & $51(51 \%)$ & $33(50,8 \%)$ & $18(51,4 \%)$ & \\
\hline & Bloga & $11(11 \%)$ & $9(13,8 \%)$ & $2(5,7 \%)$ & \\
\hline
\end{tabular}

ŽE - židininė epilepsija, GE - generalizuota epilepsija, VNE - vaistai nuo epilepsijos

*Demografinių ir klinikinių duomenų priklausomybė nuo epilepsijos formos

${ }^{1} \chi^{2}$ testas, ${ }^{2}$ Fišerio tikslusis kriterijus, ${ }^{3}$ Mann-Whitney U testas 
diana ir standartiniu nuokrypiu; kokybiniai kintamieji dažniu ir procentais. Kiekybinių duomenų skirstinio normalumui patikrinti naudotas Kolmogorovo-Smirnovo testas. Kiekybiniai duomenys, neturèję normalaus skirstinio, lyginti naudojant neparametrini Mann-Whitney $\mathrm{U}$ testą. Kokybinių duomenų kintamojo pasiskirstymui grupėse patikrinti naudotas Chi kvadrato $\left(\chi^{2}\right)$ testas, tikslusis Fišerio kriterijus (kai grupeje yra $<5$ atsakymai). Statistiškai reikšmingas skirtumas laikytas tuomet, kai reikšmingumo lygmuo $\mathrm{p}<0,05$. Tiesiniam ryšiui tarp anketos atsakymų apie miego bei VNE vartojimo drausmingumą ir demografinių, klinikinių bei veiksnių, susijusių su VNE režimo laikymusi, naudoti Pearsono (kiekybiniams duomenims) ir Spearmano (kokybiniams duomenims) koreliacijos koeficientai. VNE vartojimo drausmingumo priklausomybei nuo klinikinių, demografinių duomenų ir faktorių, susijusių su VNE vartojimo drausmingumu, apskaičiuoti naudota dvinarè logistinė regresija.

\section{REZULTATAI}

I galutinę analizę ịtraukta 100 anketų: 65 (65 \%) respondentai sirgo ŽE ir 35 (35\%) - GE. Daugiau kaip pusè $(62 \%)$ apklaustujų - $\leq 40$ metų. Sergantieji ŽE buvo statistiškai reikšmingai vyresni $(p=0,038)$, susirgę vyresniame amžiuje $(p=0,000)$ ir sergantys trumpiau $(p=0,045)$, lyginant su sergančiaisiais GE. Didesnę dali (53,9 \%) sergančiųjų ŽE grupẻje sudarẻ vyrai (sergančiųjų GE grupėje $-28,6 \%$ vyrų) $(\mathrm{p}=0,015)$, buvo daugiau bedarbių ir pensininkų ( $p=0,046)$. Sergantieji ŽE statistiškai reikšmingai dažniau patyrè priepuolius $(R=0,21, p=0,04)$. Visi demografiniai ir klinikiniai ŽE ir GE sergančių asmenų duomenys pateikti 1 lentelèje.

\section{VNE vartojimo drausmingumas ir veiksniai, susije su VNE režimo nesilaikymu}

Beveik trečdalis (30 \%) respondentų nedrausmingai vartojo paskirtus VNE ir nesilaikè paskirto gydymo režimo.

2 lentelè. Faktoriai, lemiantys ŽE ir GE sergančių asmenų VNE vartojimo drausmingumą

\begin{tabular}{|c|c|c|c|c|c|c|}
\hline \multicolumn{2}{|c|}{ Faktoriai, lemiantys VNE vartojimo drausmingumą } & \multirow{2}{*}{$\begin{array}{l}\begin{array}{l}\text { Visi duome- } \\
\text { nys, N (\%) }\end{array} \\
68(68 \%) \\
\end{array}$} & \multirow{2}{*}{$\begin{array}{l}\text { ŽE, N (\%) } \\
42(64,6 \%) \\
\end{array}$} & \multirow{2}{*}{$\begin{array}{l}\text { GE, N (\%) } \\
26(74,3 \%) \\
\end{array}$} & \multirow{3}{*}{$\begin{array}{l}\text { p reikšmé* } \\
p=0,199^{1}\end{array}$} & \multirow{3}{*}{$\begin{array}{c}\begin{array}{c}\text { Koreliacija } \\
\mathbf{R} \text { reikšmé } \\
\text { (p reikšmė) }\end{array} \\
R=-0,13 \\
(p=0,203)\end{array}$} \\
\hline \multirow[t]{2}{*}{ Pamiršo išgerti VNE } & Taip & & & & & \\
\hline & $\mathrm{Ne}$ & $32(32 \%)$ & $23(35,4 \%)$ & $9(25,7 \%)$ & & \\
\hline \multirow{2}{*}{$\begin{array}{l}\text { Vartojo VNE, nesilaikydami } \\
\text { nurodyto gydymo režimo }\end{array}$} & Taip & $16(16 \%)$ & $9(13,9 \%)$ & $7(20 \%)$ & \multirow[t]{2}{*}{$\mathrm{p}=0,423^{1}$} & \multirow{2}{*}{$\begin{array}{l}\mathrm{R}=-0,08 \\
(\mathrm{p}=0,886)\end{array}$} \\
\hline & $\mathrm{Ne}$ & $84(84 \%)$ & $56(86,1 \%)$ & $28(80 \%)$ & & \\
\hline \multirow{2}{*}{$\begin{array}{l}\text { Nevartoja VNE, kai pagerėja } \\
\text { būklė }\end{array}$} & Taip & $8(8 \%)$ & $7(10,8 \%)$ & $1(2,9 \%)$ & \multirow[t]{2}{*}{$\mathrm{p}=0,255^{2}$} & \multirow{2}{*}{$\begin{array}{c}\mathrm{R}=0,14 \\
(\mathrm{p}=0,167)\end{array}$} \\
\hline & $\mathrm{Ne}$ & $92(92 \%)$ & $58(89,2 \%)$ & $34(97,1 \%)$ & & \\
\hline \multirow{2}{*}{$\begin{array}{l}\text { Savarankiškai sumažino VNE } \\
\text { dozę, suretėjus priepuoliams }\end{array}$} & Taip & $11(11 \%)$ & $7(10,8 \%)$ & $4(11,4 \%)$ & \multirow[t]{2}{*}{$\mathrm{p}=1^{2}$} & \multirow{2}{*}{$\begin{array}{c}R=-0,1 \\
(p=0,921)\end{array}$} \\
\hline & $\mathrm{Ne}$ & $89(89 \%)$ & $58(89,2 \%)$ & $31(88,6 \%)$ & & \\
\hline \multirow{2}{*}{$\begin{array}{l}\text { Savarankiškai nutraukė VNE, } \\
\text { būklei pablogèjus }\end{array}$} & Taip & $5(5 \%)$ & $4(6,2 \%)$ & $1(2,9 \%)$ & \multirow[t]{2}{*}{$\mathrm{p}=0,655^{2}$} & \multirow{2}{*}{$\begin{array}{c}R=0,07 \\
(p=0,476)\end{array}$} \\
\hline & $\mathrm{Ne}$ & $95(95 \%)$ & $61(93,4 \%)$ & $34(97,1 \%)$ & & \\
\hline \multirow{2}{*}{$\begin{array}{l}\text { Savarankiškai nutraukė VNE } \\
\text { vartojimą, kai atsirado } \\
\text { šalutinių reiškinių }\end{array}$} & Taip & $12(12 \%)$ & $9(13,9 \%)$ & $3(8,6 \%)$ & \multirow[t]{2}{*}{$\mathrm{p}=0,533^{2}$} & \multirow{2}{*}{$\begin{array}{c}\mathrm{R}=0,08 \\
(\mathrm{p}=0,444)\end{array}$} \\
\hline & $\mathrm{Ne}$ & $88(88 \%)$ & $56(86,1 \%)$ & $32(91,4 \%)$ & & \\
\hline \multirow{3}{*}{$\begin{array}{l}\text { Užmiršta išgerti visus savo } \\
\text { vartojamus vaistus }\end{array}$} & Niekada / retai & $69(69 \%)$ & $45(69,2 \%)$ & $24(68,6 \%)$ & \multirow[t]{3}{*}{$\mathrm{p}=0,750^{1}$} & \multirow{3}{*}{$\begin{array}{l}R=-0,01 \\
(p=0,932)\end{array}$} \\
\hline & \begin{tabular}{|l|} 
Kartais \\
\end{tabular} & $30(30 \%)$ & $19(29,2 \%)$ & $11(31,4 \%)$ & & \\
\hline & Dažnai & $1(1 \%)$ & $1(1,6 \%)$ & $0(0 \%)$ & & \\
\hline \multirow{5}{*}{$\begin{array}{l}\text { Pamiršimo išgerti VNE } \\
\text { dažnumas }\end{array}$} & Niekada & $37(37 \%)$ & $26(40 \%)$ & $11(31,4 \%)$ & \multirow[t]{5}{*}{$\mathrm{p}=0,689^{1}$} & \multirow{5}{*}{$\begin{array}{c}\mathrm{R}=0,02 \\
(\mathrm{p}=0,872)\end{array}$} \\
\hline & Labai retai & $50(50 \%)$ & $31(47,7 \%)$ & $19(54,3 \%)$ & & \\
\hline & Kelis kartus per mėnesi & $11(11 \%)$ & $6(9,2 \%)$ & $5(14,3 \%)$ & & \\
\hline & \begin{tabular}{|l|} 
Kartą per savaitę \\
\end{tabular} & $1(1 \%)$ & $1(1,5 \%)$ & $0(0 \%)$ & & \\
\hline & Kasdien & $1(1 \%)$ & $1(1,5 \%)$ & $0(0 \%)$ & & \\
\hline \multirow{4}{*}{$\begin{array}{l}\text { Mažesnės, nei paskirta, dozės } \\
\text { vartojimo dažnumas }\end{array}$} & Niekada & $76(76 \%)$ & $52(80 \%)$ & $24(68,6 \%)$ & \multirow[t]{4}{*}{$\mathrm{p}=0,506^{1}$} & \multirow{4}{*}{$\begin{array}{c}\mathrm{R}=0,12 \\
(\mathrm{p}=0,234)\end{array}$} \\
\hline & \begin{tabular}{|l|} 
Labai retai \\
\end{tabular} & $19(19 \%)$ & $11(16,9 \%)$ & $8(22,8 \%)$ & & \\
\hline & Kelis kartus per mėnesi & $3(3 \%)$ & $1(1,5 \%)$ & $2(5,7 \%)$ & & \\
\hline & Kasdien & $2(2 \%)$ & $1(1,5 \%)$ & $1(2,9 \%)$ & & \\
\hline \multirow{2}{*}{$\begin{array}{l}\text { Priepuoliai dažnėja, kai } \\
\text { nesilaiko gydymo režimo }\end{array}$} & Taip & $12(17,6 \%)$ & $8(19,5 \%)$ & $4(14,8 \%)$ & $\mathrm{p}=0,751^{2}$ & $\mathrm{R}=0,06$ \\
\hline & $\mathrm{Ne}$ & $56(82,4 \%)$ & $33(80,5 \%)$ & $23(85,2 \%)$ & & $(p=0,625)$ \\
\hline
\end{tabular}

ŽE - židininè epilepsija, GE - generalizuota epilepsija, VNE - vaistai nuo epilepsijos

*İvairių faktorių, lemiančių VNE vartojimo drausmingumą, priklausomybẻ nuo epilepsijos formos

${ }^{1} \chi^{2}$ testas, ${ }^{2}$ Fišerio tikslusis kriterijus 
Vaistų vartojimo nedrausmingumas sergančiųjų ŽE ir GE grupėse nesiskyrè - netvarkingai VNE vartoja 29,2 \% sergančiujų ŽE ir 31,4 \% - GE (p = 0,819). Sergančiųų skirtingomis epilepsijos formomis grupèse neradome ir skirtu- mų tarp faktorių, turinčių įtakos VNE vartojimo drausmingumui $(\mathrm{p}>0,05)$ (2 lentelè).

Statistiškai reikšmingo amžiaus skirtumo drausmingai ir nedrausmingai VNE vartojančių asmenų grupėse nera-

3 lentelè. Duomenys apie epilepsiją, priepuolius, VNE vartojimą, gretutines ligas, sveikatos būklę ir kt. drausmingai ir nedrausmingai VNE vartojančių grupèse

\begin{tabular}{|c|c|c|c|c|c|c|}
\hline \multicolumn{2}{|l|}{ Klinikiniai duomenys } & $\begin{array}{l}\text { Visi pacien- } \\
\text { tai, } N(\%)\end{array}$ & $\begin{array}{c}\text { Drausmingai } \\
\text { vartoja vaistus, } \\
\mathbf{N}(\%)\end{array}$ & \begin{tabular}{|c} 
Nedrausmingai \\
vartoja vaistus, \\
N (\%)
\end{tabular} & p reikšmė* & $\begin{array}{l}\text { Koreliacija } \\
\text { R reikšmė } \\
\text { (p reikšmė) }\end{array}$ \\
\hline \multicolumn{2}{|c|}{ Ligos trukmė (mediana $\pm \mathrm{SN}$, metais) } & $9,5 \pm 11$ & $7 \pm 10,9$ & $16,5 \pm 12,9$ & $\mathrm{p}=\mathbf{0 , 0 2 2 ^ { 2 }}$ & $\begin{array}{c}\mathrm{R}=-0,11 \\
(\mathrm{p}=0,288)\end{array}$ \\
\hline \multicolumn{2}{|c|}{$\begin{array}{l}\text { Susirgimo epilepsija amžius (mediana } \pm \mathrm{SN} \text {, } \\
\text { metais) }\end{array}$} & $21,5 \pm 17$ & $21,5 \pm 17,5$ & $21,5 \pm 15,3$ & $\mathrm{p}=0,381^{2}$ & $\begin{array}{c}\mathrm{R}=0,23 \\
(\mathrm{p}=0,021)\end{array}$ \\
\hline \multirow{3}{*}{$\begin{array}{l}\text { Vartojamų VNE } \\
\text { skaičius }\end{array}$} & $1 \mathrm{VNE}$ & $54(47 \%)$ & $38(54,3 \%)$ & $16(53,3 \%)$ & \multirow[t]{3}{*}{$\mathrm{p}=0,948^{1}$} & \multirow{3}{*}{$\begin{array}{c}\mathrm{R}=-0,01 \\
(\mathrm{p}=0,955)\end{array}$} \\
\hline & $2 \mathrm{VNE}$ & $28(28 \%)$ & $19(27,1 \%)$ & $9(30 \%)$ & & \\
\hline & $\geq 3 \mathrm{VNE}$ & $18(18 \%)$ & $13(18,6 \%)$ & $5(16,7 \%)$ & & \\
\hline \multirow{2}{*}{$\begin{array}{l}\text { Priepuoliai } \\
\text { kontroliuojami }\end{array}$} & Taip & $76(76 \%)$ & $56(80 \%)$ & $20(66,7 \%)$ & \multirow[t]{2}{*}{$\mathrm{p}=0,153^{1}$} & \multirow{2}{*}{$\begin{array}{c}\mathrm{R}=0,14 \\
(\mathrm{p}=0,156)\end{array}$} \\
\hline & $\mathrm{Ne}$ & $24(24 \%)$ & $14(20 \%)$ & $10(33,3 \%)$ & & \\
\hline \multirow[t]{4}{*}{ Priepuoliai kartojasi } & Kasdien & $6(6 \%)$ & $4(5,6 \%)$ & $2(6,6 \%)$ & \multirow{4}{*}{$p=0,033^{1}$} & \multirow{4}{*}{$\begin{array}{c}R=-0,21 \\
(p=0,032)\end{array}$} \\
\hline & Kelis kartus per mėnesi & $24(24 \%)$ & $13(18,6 \%)$ & $11(36,7 \%)$ & & \\
\hline & Kelis kartus per metus & $34(34 \%)$ & $23(32,9 \%)$ & $11(36,7 \%)$ & & \\
\hline & $\geq 1$ metus priepuolių nebuvo & $36(36 \%)$ & $30(42,9 \%)$ & $6(20 \%)$ & & \\
\hline \multirow[t]{6}{*}{ Gretutinès ligos } & Širdies ir kraujagyslių liga & $9(9 \%)$ & $9(12,9 \%)$ & $0(0 \%)$ & \multirow[t]{6}{*}{$\mathrm{p}=0,399^{3}$} & \multirow{6}{*}{$\begin{array}{c}R=0,05 \\
(p=0,588)\end{array}$} \\
\hline & Kvėpavimo sistemos liga & $3(3 \%)$ & $1(1,4 \%)$ & $2(6,7 \%)$ & & \\
\hline & Psichiatrinė liga & $13(13 \%)$ & $8(11,4 \%)$ & $5(16,7 \%)$ & & \\
\hline & Endokrininè liga & $3(3 \%)$ & $2(2,9 \%)$ & $1(3,3 \%)$ & & \\
\hline & Kita & $18(18 \%)$ & $13(18,6 \%)$ & $5(16,7 \%)$ & & \\
\hline & Kita liga nesergu & $64(64 \%)$ & $46(65,7 \%)$ & $18(60 \%)$ & & \\
\hline \multirow{2}{*}{$\begin{array}{l}\text { Gydymo VNE } \\
\text { trukmé }\end{array}$} & $<5$ metus & $41(41 \%)$ & $31(44,3 \%)$ & $10(33,3 \%)$ & \multirow{2}{*}{$\mathrm{p}=0,308^{1}$} & \multirow{2}{*}{$\begin{array}{c}\mathrm{R}=0,1 \\
(\mathrm{p}=0,312)\end{array}$} \\
\hline & $>5$ metus & $59(59 \%)$ & $39(55,7 \%)$ & $20(66,7 \%)$ & & \\
\hline \multirow{4}{*}{$\begin{array}{l}\text { VNE dozių skaičius } \\
\text { per dieną }\end{array}$} & 1 & $8(8 \%)$ & $2(2,9 \%)$ & $6(20 \%)$ & \multirow[t]{4}{*}{$\mathrm{p}=\mathbf{0 , 0 3 2 ^ { 1 }}$} & \multirow{4}{*}{$\begin{array}{c}\mathbf{R}=\mathbf{- 0 , 2} \\
(\mathbf{p}=\mathbf{0 , 0 5 1})\end{array}$} \\
\hline & 2 & $76(76 \%)$ & $60(85,7 \%)$ & $21(70 \%)$ & & \\
\hline & 3 & $10(10 \%)$ & $7(10 \%)$ & $3(10 \%)$ & & \\
\hline & $>3$ & $1(1 \%)$ & $1(1,4 \%)$ & $0(0 \%)$ & & \\
\hline \multirow{3}{*}{$\begin{array}{l}\text { Visų vartojamų } \\
\text { vaistų skaičius }\end{array}$} & 1 & $40(40 \%)$ & $28(40 \%)$ & $12(40 \%)$ & \multirow[t]{3}{*}{$\mathrm{p}=0,878^{1}$} & \multirow{3}{*}{$\begin{array}{c}\mathrm{R}=0,02 \\
(\mathrm{p}=0,851)\end{array}$} \\
\hline & $2-5$ & $55(55 \%)$ & $39(55,7 \%)$ & $16(53,3 \%)$ & & \\
\hline & $>5$ & $5(5 \%)$ & $3(4,3 \%)$ & $2(6,7 \%)$ & & \\
\hline \multirow{2}{*}{\begin{tabular}{|l|} 
VNE sukelti nepagei- \\
daujami reiškiniai
\end{tabular}} & Taip & $33(33 \%)$ & $20(28,6 \%)$ & $13(43,3 \%)$ & \multirow[t]{2}{*}{$\mathrm{p}=0,150^{1}$} & \multirow{2}{*}{$\begin{array}{l}\mathrm{R}=-0,14 \\
(\mathrm{p}=0,153)\end{array}$} \\
\hline & $\mathrm{Ne}$ & $67(67 \%)$ & $50(71,4 \%)$ & $17(56,7 \%)$ & & \\
\hline & Gydantis gydytojas neurologas & $89(89 \%)$ & $65(92,9 \%)$ & $24(80 \%)$ & $\mathrm{p}>0,05^{3}$ & $\mathrm{R}=0$ \\
\hline epilepsiją, gydymo & Šeimos gydytojas & $21(21 \%)$ & $11(15,7 \%)$ & $10(33,3 \%)$ & & $(\mathrm{p}=0,978)$ \\
\hline $\begin{array}{l}\text { rezımą, vaistų } \\
\text { vartojima šaltiniai }\end{array}$ & \begin{tabular}{|l|} 
Vaistininkas \\
\end{tabular} & $3(3 \%)$ & $2(2,9 \%)$ & $1(3,3 \%)$ & & \\
\hline & Informaciniai vaistų lapeliai & $4(4 \%)$ & $4(5,7 \%)$ & $0(0 \%)$ & & \\
\hline & Internetas & $22(22 \%)$ & $18(25,7 \%)$ & $4(13,3 \%)$ & & \\
\hline & Giminės, draugai, kaimynai & $1(1 \%)$ & $0(0 \%)$ & $1(3,3 \%)$ & & \\
\hline Subjektyvus & Gera & $38(38 \%)$ & $31(44,3 \%)$ & $7(23,4 \%)$ & $\mathrm{p}=0,141^{1}$ & $\mathrm{R}=0,17$ \\
\hline sveikatos būklès & Vidutiniška & $51(51 \%)$ & $32(45,7 \%)$ & $19(63,3 \%)$ & & 86) \\
\hline & Bloga & $11(11 \%)$ & $7(10 \%)$ & $4(13,3 \%)$ & & \\
\hline
\end{tabular}

VNE - vaistai nuo epilepsijos

*Drausmingo ir nedrausmingo VNE vartojimo priklausomybė nuo ịvairių duomenų apie epilepsiją, priepuolius, VNE vartojimą, sveikatos būklę.

${ }^{1} \chi^{2}$ testas, ${ }^{2}$ Mann-Whitney U testas, ${ }^{3} \chi^{2}$ testas, nustatyta priklausomybe tarp serga / neserga kita liga ir drausmingai / nedrausmingai vartoja VNE 
dome $(p=0,447)$. VNE vartojimo drausmingumas nuo lyties $(p=0,826)$, gyvenimo sąlygų $(p=0,632)$, išsilavinimo $(\mathrm{p}=0,429)$, užimtumo $(\mathrm{p}=0,329)$, žalingu ịpročių $(\mathrm{p}=0,274)$ nepriklauso. Pusė $(53,3 \%)$ gyvenančių kaime ir $25,9 \%$ gyvenančiu mieste VNE vartoja nedrausmingai $(\mathrm{p}=0,032)$.

Duomenys apie epilepsiją, priepuolius, VNE vartojimą, gretutines ligas, sveikatos būklę ir kt. drausmingai ir nedrausmingai VNE vartojančių grupèse pateikti 3 lentelèje.

Priepuoliai bent kartą per metus kartojasi $80 \%$ nedrausmingai ir 57,1\% drausmingai VNE vartojančių asmenu ( $p=0,033$ ). Duomenys apie VNE vartojimo drausmingumą lemiančius faktorius pateikti 4 lentelèje.

\section{VNE dozės praleidimo priežastys}

Bent kartą pamiršę išgerti VNE nurodė $68 \%$ respondentų - 92,3\% tiriamųư, kuriems neužtenka žinių apie epilepsiją bei VNE vartojimą ir 62,1 \%, kuriems jų užten$\mathrm{ka}(\mathrm{p}=0,032)$. VNE išgerti pamiršo $74,6 \%$ moterų ir $55,6 \%$ vyru $(p=0,046)$, nors $83,6 \%$ moterų ir $91,1 \%$ vyru užtenka žinių apie epilepsiją ir VNE vartojimą $(p=0,373)$. Net $82,4 \%$ respondentų, kurie nesilaike paskirto gydymo režimo, nurodè, kad dažniausia VNE dozių praleidimo priežastis yra užmaršumas. Kitos dažniausios vaistų nevartojimo priežastys pateikiamos paveiksliuke.

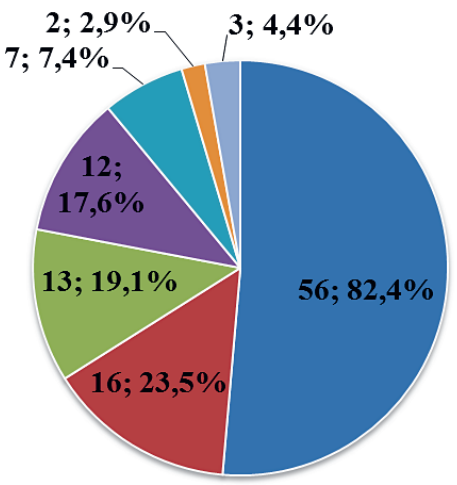

namiršote

Buvote išvyke ir neturejote pasième su savimi VNE

- Pasibaigè išrašyti VNE ir nespejjote nueiti pas gydytoja išsirašyti nauju

- Vartojote alkoholi

- Atsirado VNE pašaliniu reiškiniu, dè to susirūpinote dèl VNE vartojimo

- Ilgą laiką nebuvo priepuolių, dèl to savarankiškai sumažinote VNE dozę ar visai nutraukete gydymą $\because$ Kita

Pav. Vaistų nuo epilepsijos dozių praleidimo priežastys

\section{Respondentų nuomonẻ apie VNE ir jų poveiki sveikatos būklei}

ŽE sergantys asmenys patikimai dažniau (47,7 \%) nei sergantieji GE $(25,7 \%)$ abejojo VNE efektyvumu ir teigiamu poveikiu sveikatos būklei $(\mathrm{p}=0,032)$. Nuomoné apie VNE ir jų poveiki sveikatos būklei nuo lyties nepriklausė $(\mathrm{p}>0,05)$. Vieniši asmenys labiau pasitiki gydymu VNE jie tiki, kad, nevartojant vaistų, sveikatos būklè būtų pra-

4 lentelè. Drausmingai ir nedrausmingai VNE vartojančių asmenų nuomonẻ apie VNE ir jų poveikị sveikatos būklei

\begin{tabular}{|c|c|c|c|c|c|c|}
\hline \multicolumn{2}{|l|}{ Teiginiai apie VNE } & $\begin{array}{c}\text { Visi } \\
\text { duomenys, } \\
\text { N (\%) }\end{array}$ & $\begin{array}{l}\text { Drausmingai } \\
\text { vartoja } \\
\text { VNE, N }(\%)\end{array}$ & \begin{tabular}{|c|} 
Nedrausmingai \\
vartoja VNE, \\
$\mathbf{N}(\%)$ \\
\end{tabular} & p reikšmé $\dot{e}^{*}$ & $\begin{array}{l}\text { Koreliacija } \\
\mathbf{R} \text { reikšmé } \\
(\mathbf{p} \text { reikšmé) }\end{array}$ \\
\hline \multirow[t]{2}{*}{$\begin{array}{l}\text { Jūsų nuomonė apie vartojamus } \\
\text { vaistus nuo epilepsijos }\end{array}$} & $\begin{array}{l}\text { Teigiama - VNE page- } \\
\text { rina sveikatos būklę }\end{array}$ & $93(93 \%)$ & $67(95,7 \%)$ & $26(86,7 \%)$ & \multirow[t]{2}{*}{$\mathrm{p}=0,193^{2}$} & \multirow[t]{2}{*}{$\begin{array}{c}R=0,16 \\
(p=0,106)\end{array}$} \\
\hline & $\begin{array}{l}\text { Neigiama - VNE nepa- } \\
\text { gerina sveikatos būklès } \\
\text { ar ją pablogina }\end{array}$ & $7(7 \%)$ & $3(4,3 \%)$ & $4(13,3 \%)$ & & \\
\hline \multirow{3}{*}{$\begin{array}{l}\text { Dabartinė sveikatos būklè } \\
\text { priklauso nuo VNE vartojimo }\end{array}$} & Sutinku & $76(76 \%)$ & $58(82,8 \%)$ & $18(60 \%)$ & \multirow[t]{3}{*}{$\mathbf{p}=\mathbf{0 , 0 4 3 ^ { 2 }}$} & \multirow{3}{*}{$\begin{array}{c}R=0,25 \\
(p=0,013)\end{array}$} \\
\hline & Abejoju & $19(19 \%)$ & $10(14,3 \%)$ & $9(30 \%)$ & & \\
\hline & Nesutinku & $5(5 \%)$ & $2(2,9 \%)$ & $3(10 \%)$ & & \\
\hline \multirow{3}{*}{$\begin{array}{l}\text { Nerimauju, kad turiu vartoti } \\
\text { VNE ir kad ilgalaikis šiu vaistų } \\
\text { vartojimas gali sukelti šalutinių } \\
\text { nepageidaujamų reiškinių }\end{array}$} & Sutinku & $42(42 \%)$ & $26(37,1 \%)$ & $16(53,3 \%)$ & \multirow[t]{3}{*}{$\mathrm{p}=0,298^{1}$} & \multirow{3}{*}{$\begin{array}{l}R=-0,11 \\
(p=0,265)\end{array}$} \\
\hline & Abejoju & $40(40 \%)$ & $31(44,3 \%)$ & $9(30 \%)$ & & \\
\hline & Nesutinku & $18(18 \%)$ & $13(18,6 \%)$ & $5(16,7 \%)$ & & \\
\hline \multirow{3}{*}{$\begin{array}{l}\text { Nevartojant VNE, sveikatos } \\
\text { būklė būtų prastesnė }\end{array}$} & Sutinku & $64(64 \%)$ & $49(70 \%)$ & $15(50 \%)$ & \multirow[t]{3}{*}{$\mathrm{p}=0,158^{1}$} & \multirow{3}{*}{$\begin{array}{c}R=0,18 \\
(p=0,068)\end{array}$} \\
\hline & Abejoju & $27(27 \%)$ & $16(22,9 \%)$ & $11(36,7 \%)$ & & \\
\hline & Nesutinku & $9(9 \%)$ & $5(7,1 \%)$ & $4(13,3 \%)$ & & \\
\hline \multirow{3}{*}{$\begin{array}{l}\text { Nerimauju, kad tampu } \\
\text { priklausomas nuo VNE }\end{array}$} & Sutinku & $27(27 \%)$ & $18(25,7 \%)$ & $9(30 \%)$ & \multirow[t]{3}{*}{$\mathrm{p}=0,776^{1}$} & \multirow{3}{*}{$\begin{array}{l}\mathrm{R}=-0,07 \\
(\mathrm{p}=0,509)\end{array}$} \\
\hline & Abejoju & $31(31 \%)$ & $21(30 \%)$ & $10(33,3 \%)$ & & \\
\hline & Nesutinku & $42(42 \%)$ & $31(44,3 \%)$ & $11(36,7 \%)$ & & \\
\hline \multirow{3}{*}{$\begin{array}{l}\text { Tik VNE padeda kontroliuoti } \\
\text { ligą ir priepuoliai tapo retesni }\end{array}$} & Sutinku & $61(61 \%)$ & $44(62,8 \%)$ & $17(56,7 \%)$ & \multirow[t]{3}{*}{$\mathrm{p}=0,715^{1}$} & \multirow{3}{*}{$\begin{array}{c}R=0,03 \\
(p=0,762)\end{array}$} \\
\hline & Abejoju & $31(31 \%)$ & $20(28,6 \%)$ & $11(36,7 \%)$ & & \\
\hline & Nesutinku & $8(8 \%)$ & $6(8,6 \%)$ & $2(6,6 \%)$ & & \\
\hline \multirow{2}{*}{$\begin{array}{l}\text { Abejoju VNE efektyvumu ir tei- } \\
\text { giamu poveikiu sveikatos būklei }\end{array}$} & Sutinku & $40(40 \%)$ & $22(31,4 \%)$ & $18(60 \%)$ & \multirow[t]{2}{*}{$\mathrm{p}=\mathbf{0 , 0 0 8 ^ { 1 }}$} & \multirow{2}{*}{$\begin{array}{c}R=\mathbf{- 0 , 2 7} \\
(\mathbf{p}=\mathbf{0 , 0 0 7})\end{array}$} \\
\hline & Nesutinku & $60(60 \%)$ & $48(68,6 \%)$ & $12(40 \%)$ & & \\
\hline
\end{tabular}

VNE - vaistai nuo epilepsijos

${ }^{1} \chi^{2}$ testas, ${ }^{2}$ Fišerio tikslusis kriterijus

*Drausmingo ir nedrausmingo VNE vartojimo priklausomybė nuo nuomonės apie VNE ir jų poveiki sveikatos būklei 
stesnè $(\mathrm{R}=-0,27, \mathrm{p}=0,006)$ ir kad tik VNE padeda kontroliuoti ligą bei retinti priepuolius $(R=-0,28, p=0,005)$, nei tie, kurie gyvena su tėvais ar šeima. Gyvenantys kaime dažniau galvoja, kad VNE nepagerina sveikatos būklès ar ją pablogina $(R=0,21 ; p=0,032)$, dažniau nerimauja, kad tampa priklausomi nuo vaistų $(\mathrm{R}=-0,21, \mathrm{p}=0,032)$, ir dažniau abejoja vaistų efektyvumu bei teigiamu poveikiu sveikatai $(R=-0,24, p=0,016)$.

Dviem trečdaliams $(71,4 \%)$ tikinčių, kad VNE nepagerina sveikatos būklès ar net ją pablogina (lyginant su 20,4 \% tikinčių, kad VNE turi teigiamą poveiki jų sveikatos būklei), priepuoliai yra nekontroliuojami ( $p=0,008)$. Trečdaliui $(37,5 \%)$ netikinčių, kad tik VNE padeda kontroliuoti ligą ir priepuoliai tapo retesni (lyginant su 14,8\% tikinčių, kad dèl VNE vartojimo priepuoliai tapo retesni), priepuoliai yra prasčiau kontroliuojami $(\mathrm{p}=0,026)$. Didžiajai daliai $(82,5 \%)$ VNE efektyvumu abejojančių respondentų (lyginant su 51,7 \% VNE efektyvumu ir teigiamu poveikiu sveikatai neabejojančių asmenų) priepuoliai pasikartoja dažniau nei kartą per metus $(p=0,001)$.

Respondentų nuomonė apie vartojamus VNE ir jų poveikị sveikatos būklei drausmingai ir nedrausmingai VNE vartojančių asmenų grupėse pateikiama 4 lentelèje.

Penktadalis $(20 \%)$ teigiančių, kad jų dabartinè būklè nepriklauso nuo VNE vartojimo, ir kurių priepuoliai yra gerai kontroliuojami (lyginant su 2,6 \% tikinčių, kad jų būklè priklauso nuo VNE), VNE vartojo mažesne doze nei paskirta $(p=0,022)$. Kiek daugiau nei pusė $(60 \%)$ tikinčių, kad jų sveikatos būklè nepriklauso nuo VNE vartojimo (lyginant su 5,3\% tikinčių, kad būklè priklauso nuo VNE vartojimo), savarankiškai sumažina VNE dozę priepuoliams suretejus $(p=0,000)$. Kiek daugiau nei pusè $(60 \%)$ netikinčių, kad jų būklè priklauso nuo VNE (lyginant su 7,9 \% tikinčių, kad VNE svarbūs kontroliuojant ligą), nutraukia VNE vartojimą atsiradus nepageidaujamų reiškinių $(\mathrm{p}=0,002)$. Respondentų nuomonè, kad jų dabartinè būklè nepriklauso nuo VNE vartojimo, silpnai, bet statistiškai reikšmingai koreliuoja su dažnesniu pamiršimu išgerti vaistus $(R=-0,29, p=0,003)$, savarankišku vaistų dozès mažinimu $(\mathrm{R}=-0,35, \mathrm{p}=0,000)$, VNE nutraukimu sumažèjus priepuolių skaičiui $(\mathrm{R}=-0,39, \mathrm{p}=0,000)$ ar atsiradus šalutinių reiškinių $(R=-0,31, p=0,002)$.

Didelè dalis $(81,8 \%)$ respondentų, kurie blogiau vertina savo sveikatos būklę (lyginant su 26,3 \% gerai savo būklę vertinančiu asmenų), abejoja VNE efektyvumu $(\mathrm{p}=0,004)$. Penktadalis asmenu $(22,2 \%)$, abejojančiu VNE efektyvumu ir teigiamu poveikiu sveikatai (lyginant su $5 \%$ VNE efektyvumu neabejojančių asmenų), nutraukia VNE vartojimą atsiradus nepageidaujamų reiškinių $(p=0,012)$.

\section{Miego režimo vertinimas}

Miego režimo vertinimas su epilepsijos forma, lytimi, priepuolių kontrole, vartojamų VNE skaičiumi nèra susijęs $(p>0,05)$. Geresnis miego kokybės vertinimas yra susijęs su geresniu sveikatos būklès vertinimu $(p=0,018)$. Trečdalis $(34,6 \%$ ) žalingų ịpročiu turinčiu asmenų nurodè, kad, pasikeitus miego režimui, nesilaiko paskirto gydymo režimo, praleidžia VNE dozes ar VNE išgeria ne tuo pačiu laiku (tą patị nurodè 13,5\% respondentų be žalingu ipročių) (p=0,018).

Prasčiau miego režimo laikosi moterys $(\mathrm{R}=-0,17$, $\mathrm{p}=0,096)$, jaunesni $(\mathrm{R}=-0,18, \mathrm{p}=0,075)$ ir trumpiau sergantys epilepsija asmenys $(R=-0,27, p=0,006)$. Blogiau miego kokybę vertina moterys $(R=0,2, p=0,041)$, vyresni

5 lentelè. Drausmingai ir nedrausmingai VNE vartojančių asmenų miego režimo vertinimas

\begin{tabular}{|c|c|c|c|c|c|c|}
\hline \multicolumn{2}{|l|}{ Duomenys apie miego režimą } & \multirow{2}{*}{$\begin{array}{c}\begin{array}{c}\text { Visi } \\
\text { duomenys, } \\
\text { N (\%) }\end{array} \\
35(35 \%) \\
\end{array}$} & \multirow{2}{*}{$\begin{array}{c}\begin{array}{c}\text { Drausmingai } \\
\text { vartoja } \\
\text { VNE, N (\%) }\end{array} \\
23(32,8 \%) \\
\end{array}$} & \multirow{2}{*}{\begin{tabular}{|c|}
$\begin{array}{c}\text { Nedrausmingai } \\
\text { vartoja VNE, } \\
\mathbf{N}(\%)\end{array}$ \\
$12(40 \%)$ \\
\end{tabular}} & \multirow{2}{*}{\begin{tabular}{|l} 
p reikšmė* \\
$p=0,565^{1}$
\end{tabular}} & \multirow{3}{*}{\begin{tabular}{|c}
$\begin{array}{r}\text { Koreliacija } \\
\mathbf{R} \text { reikšme } \\
(\mathbf{p} \text { reikšme் }\end{array}$ \\
$\mathrm{R}=-0,1$ \\
$(\mathrm{p}=0,337)$
\end{tabular}} \\
\hline \multirow[t]{3}{*}{ Nakties miego trukmè (valandomis) } & $<7$ & & & & & \\
\hline & $7-9$ & $58(58 \%)$ & $41(58,6 \%)$ & $17(56,7 \%)$ & & \\
\hline & $>9$ & $7(7 \%)$ & $6(8,6 \%)$ & $1(3,3 \%)$ & & \\
\hline \multirow{2}{*}{$\begin{array}{l}\text { Miego režimo laikymasis (atsigulimas } \\
\text { ir kèlimasis tuo pačiu laiku) }\end{array}$} & Taip & $47(47 \%)$ & $38(54,3 \%)$ & $9(30 \%)$ & \multirow[t]{2}{*}{$\mathrm{p}=\mathbf{0 , 0 2 7 ^ { 1 }}$} & \multirow{2}{*}{$\begin{array}{c}R=0,22 \\
(p=0,026)\end{array}$} \\
\hline & $\mathrm{Ne}$ & $53(53 \%)$ & $32(45,7 \%)$ & $21(70 \%)$ & & \\
\hline \multirow[t]{5}{*}{ Miego kokybės vertinimas } & Labai gerai & $8(8 \%)$ & $5(7,1 \%)$ & $3(10 \%)$ & \multirow[t]{5}{*}{$\mathrm{p}=0,263^{1}$} & \multirow{5}{*}{$\begin{array}{c}\mathrm{R}=0,08 \\
(\mathrm{p}=0,456)\end{array}$} \\
\hline & Gerai & $42(42 \%)$ & $34(48,6 \%)$ & $8(26,7 \%)$ & & \\
\hline & Vidutiniškai & $42(42 \%)$ & $25(35,7 \%)$ & $17(56,7 \%)$ & & \\
\hline & Blogai & $7(7 \%)$ & $5(7,1 \%)$ & $2(6,6 \%)$ & & \\
\hline & Labai blogai & $1(1 \%)$ & $1(1,4 \%)$ & $0(0 \%)$ & & \\
\hline \multirow{2}{*}{$\begin{array}{l}\text { Miego trūkumas (<7 val. naktị) dažnina } \\
\text { priepuolius }\end{array}$} & Taip & $43(43 \%)$ & $29(41,4 \%)$ & $14(46,7 \%)$ & \multirow[t]{2}{*}{$\mathrm{p}=0,628^{1}$} & \multirow{2}{*}{$\begin{array}{l}\mathrm{R}=-0,05 \\
(\mathrm{p}=0,632)\end{array}$} \\
\hline & $\mathrm{Ne}$ & $57(57 \%)$ & $41(58,6 \%)$ & $16(53,3 \%)$ & & \\
\hline \multirow{2}{*}{$\begin{array}{l}\text { Pasikeitus miego režimui, laikomasi } \\
\text { VNE vartojimo režimo (VNE geriami } \\
\text { tuo pačiu laiku, nepraleidžiamos dozės) }\end{array}$} & Taip & $81(81 \%)$ & $56(80 \%)$ & $25(83,3 \%)$ & \multirow[t]{2}{*}{$\mathrm{p}=0,698^{1}$} & \multirow{2}{*}{$\begin{array}{c}\mathrm{R}=-0,04 \\
(\mathrm{p}=0,701)\end{array}$} \\
\hline & $\mathrm{Ne}$ & $19(19 \%)$ & $14(20 \%)$ & $5(16,7 \%)$ & & \\
\hline
\end{tabular}

VNE - vaistai nuo epilepsijos

*Drausmingo ir nedrausmingo VNE vartojimo priklausomybė nuo įvairių su miego režimu susijusių faktorių,

${ }^{1} \chi^{2}$ testas 
( $\mathrm{R}=0,27, \mathrm{p}=0,006)$, dažnesnius priepuolius patiriantys $(\mathrm{R}=-0,27, \mathrm{p}=0,008)$ ir daugiau VNE vartojantys $(\mathrm{R}=0,27, \mathrm{p}=0,006)$ respondentai. Nuomonè, kad miego trūkumas didina priepuolių dažnį, koreliuoja su moteriška lytimi $(\mathrm{R}=-0,18, \mathrm{p}=0,079)$, vyresniu amžiumi $(\mathrm{R}=0,19$, $\mathrm{p}=0,057)$ ir ilgesne ligos trukme $(\mathrm{R}=0,25, \mathrm{p}=0,013)$.

Miego režimo vertinimas ir jo įtaka drausmingam VNE vartojimui pateikti 5 lentelèje.

\section{Logistinės regresijos rezultatai}

I logistinės regresijos modelị îtraukti visi faktoriai, lemiantys VNE vartojimo nedrausmingumą $(p<0,05)$ : gyvenamoji vieta, priepuolių dažnumas, vartojamų VNE dozių dažnumas, sunkumai, patiriami laikantis paskirto VNE vartojimo, nuomonė apie VNE, miego režimo nesilaikymas. Dvinarè logistinė regresija parodė, kad trys kintamieji yra reikšmingai susiję su paskirtų VNE vartojimo nedrausmingumu: gyvenimas kaimo vietovejje ( $p=0,0495$, $\mathrm{OR}=4,48,95 \%$ CI 1-20,05), dažnesnis priepuolių pasikartojimas $(\mathrm{p}=0,0247, \mathrm{OR}=0,46,95 \%$ CI 0,23-0,9), mažiau kartų per dieną vartojami VNE ( $\mathrm{p}=0,0016$, $\mathrm{OR}=0,25,95 \%$ CI $0,1-0,59)$.

Faktorių, lemiančių nedrausmingą VNE vartojimą, priklausomybė nuo epilepsijos formos

Nedrausmingai VNE vartojančių asmenų, sergančių ŽE ir GE, ligos trukmè statistiškai reikšmingai nesiskiria $(p=0,154)$. Faktorių, lemiančių nedrausmingą VNE vartojimą, pasiskirstymas nuo epilepsijos formos nepriklauso: $31,6 \%$ sergančiujų ŽE ir 18,2 \% - GE gyvena kaime ( $p=0,672), 84,2$ \% sergančiujų ŽE ir 72,7 \% - GE priepuoliai kartojasi bent kartą per metus ( $p=0,493), 68,4 \%$ asmenų, sergančių ŽE, ir 72,7 \% - GE nesilaiko normalaus miego režimo $(\mathrm{p}=1), 52,6 \%$ sergančiujjų ŽE ir 72,7 \% GE tiki, kad jų dabartinė būklè priklauso nuo VNE vartojimo $(p=0,325)$, ir $31,6 \%$ sergančiujų ŽE ir 54,6 \% - GE abejoja VNE efektyvumu ( $\mathrm{p}=0,179), 31,6 \%$ sergančiųu ŽE ir 27,3\% - GE asmenų dažniau sunku laikytis paskirto VNE vartojimo režimo $(\mathrm{p}=0,724)$. Nedrausmingai VNE vartojančių grupejje mažiau kartų per dieną VNE statistiškai reikšmingai dažniau vartoja sergantys GE - 45,5\% ir 5,3\% sergančių ŽE asmenų (p = 0,019).

\section{REZULTATU APTARIMAS}

Šiame tyrime nagrinėjome epilepsija sergančių asmenų VNE vartojimo ir miego režimo laikymosi drausmingumą židinine ir generalizuota epilepsijomis sergančių asmenų grupėse. Atliktų klinikinių tyrimų duomenimis, tikslus gydytojo paskirtų VNE nevartojimo dažnis nèra žinomas ir varijuoja priklausomai nuo tyrimų metodologijos $[6,7]$. Šio darbo rezultatai praktiškai nesiskyrè nuo JAV ir Jungtinėje Karalystejje (JK) atliktų tyrimų rezultatų. Hovinga ir kt. (JAV) savo tyrime naudojo panašią nedrausmingo
VNE vartojimo įvertinimo metodiką, jų tyrimo respondentai $(n=408)$ nesiskyrè nuo lietuvių savo amžiumi, lytimi ir išsilavinimu, nedrausmingas VNE vartojimas siekẻ $29 \%$ (mūsų - 30 \%) [20]. JK atlikto tyrimo metu buvo vertinti anketiniai (subjektyvūs) ir vaisto koncentracijos kraujo serume (objektyvūs) duomenys, nustatyta, kad nedrausmingai VNE vartoja 26,9 \% (iš 438) pacientų [28]. Kituose tyrimuose nedrausmingo VNE vartojimo dažnis buvo šiek tiek didesnis ir svyravo nuo 36,4 iki 39,7 \% [13, 25, 29, 30]. Rezultatų skirtumą galimai lėmè tyrimo metodika: anglų atliktame tyrime nedrausmingam VNE vartojimui ivertinti naudotas ESMS (angl. Epilepsy Self-Management Scale) klausimynas ir matuota VNE koncentracija kraujo serume [30], Etiopijos ir Kinijos mokslininkai naudojo MMAS-8 (angl. Morisky Medication Adherence Scale-8) skalę [13, 29], Šiaurès Karolinos tyrejjai tyrè VNE koncentraciją kraujo serume [25]. Tyrimuose skyrèsi tiriamųu amžius, moterų ir vyrų santykis, priepuolių pasikartojimo dažnis ar gyvenamoji vieta. Respondentų amžiaus mediana (metais) anglų tyrime buvo 49,9 [30], Etiopijos 27 [13], Kinijos - 28 [29], mūsų - 37,5 metų; skirtingas moteru ir vyrų santykis: Etiopijos - 58,7 \% vyrų [13], o mūsų - $45 \%$; ilgiau nei metus nebuvo priepuolių: anglų 59,1 \% [30], mūsų - $36 \%$ tirtujų; kaime gyvena: $75 \%$ Etiopijoje [13], 42,9 \% - Kinijoje [29], 15 \% mūsu tirtų respondentų. Mūsų tyrime mažesnị nedrausmingą VNE vartojimą galejo lemti atminties problemos, didesnis atsakingumas, baimè dẻl sveikatos būklès ir subjektyvi anoniminè respondentų nuomonė. Faught atliktoje apžvalgoje nustatyta, kad, atliekant anonimines respondentų apklausas, padideja šališkumas, apklausos rezultatus gali lemti atminties problemos ar neatsakingas anketos užpildymas [6]. Daug didesnị $(48,1 \%)$, lyginant su mūsų rezultatais, nedrausmingą VNE vartojimą, atlikę anoniminę ESA apklausą ( $n=368$ ), rado kinai, užduodami tik du klausimus ar per paskutinị mėnesį sergantysis bent kartą neišgėrè VNE, ar nutraukė gydymą VNE, ir nedrausmingam gydymuisi priskirdami visus, kurie bent ị vieną klausimą atsakẻ teigiamai [16]. Tam galèjo turèti įtakos klausimyno nespecifiškumas, nes VNE išgerti bent vieną kartą per mėnesi pamiršta nemaža dalis VNE vartojančių asmenų. Be to, kitose studijose toks pamiršimo dažnis nèra laikomas nedrausmingu VNE vartojimu. Prancūzu atlikto tyrimo ( $n=263$ ) metu naudota autorių sudaryta 23 klausimų anketa [18]. Jų rezultato skirtumą (21\%) nuo mūsų galèjo lemti tai, kad $78 \%$ tiriamujuc buvo jauni asmenys ( $\leq 45 \mathrm{~m}$.); kadangi ị tyrimą buvo ịtraukti vaikai ir paaugliai, kurių VNE vartojimą prižiūri tėvai, tai lemia drausmingesnị VNE vartojimą [18]. Mes ị tyrimą ịtraukẻme tik vyresnius nei 18 metų asmenis, $38 \%$ buvo $\geq 40$ metų amžiaus.

Nustatyta, kad vaistų vartojimo režimo laikymosi drausmingumas nuo epilepsijos formos nepriklauso. Tokius pat rezultatus gavo ir kiti tyrèjai $[8,16,29]$. Ferrari ir kt. (n = 385) nustatè, kad $53 \%$ sergančių ŽE ir $58 \%$ - GE [8], atitinkamai Guo ir kt. ( $\mathrm{n}=184)$ nustatè, kad $39 \%$ sergančių ŽE ir $44 \%$ - GE VNE vartoja nedrausmingai [29]. Skirtingą rezultatą gavo Gurumurthy ir kt. $(n=451)$, jų tyrime pacientai, sergantys GE, dažniau nesilaikè paskirto 
VNE vartojimo režimo. Viena iš priežasčių galètų būti ta, kad sergantieji GE rečiau nei sergantieji ŽE patiria priepuolius, nors ryšio tarp priepuolių dažnumo ir nedrausmingo vaistų vartojimo šioje studijoje taip pat nenustatyta [10].

Mūsų tyrime VNE vartojimo drausmingumas nuo lyties nepriklausè, tokius pat rezultatus gavo prancūzai $(n=263)$, vokiečiai $(n=31317)$, kinai $(n=382)$ ir amerikiečiai $(n=408)[16,18,20,27]$. Tačiau brazilų tyrime moterys VNE vartoja drausmingiau už vyrus ir tai aiškinama didesniu moterų rūpinimusi savo sveikata, jos dažniau ir greičiau kreipiasi pagalbos, pablogejjus sveikatos būklei, ir drausmingiau laikosi vaistų vartojimo režimo [8].

Nustatėme, kad patikimai dažniau gydymo režimo nesilaiko gyvenantys kaimo vietovejje, nors kinai savo tyrime skirtumo tarp gyvenamosios vietos nerado [16]. Kitose šalyse ryšys tarp VNE vartojimo drausmingumo ir gyvenamosios vietos (miestas ar kaimas) nebuvo vertintas, o VNE vartojimo drausmingumas nuo išsilavinimo [20, 28, 29], užimtumo [29] ir gaunamų pajamų [20] nepriklausè. Tokie pat rezultatai gauti ir mūsų tyrime - VNE vartojimo drausmingumas nuo respondentų išsilavinimo ir užimtumo nepriklauso, o socioekonominio statuso mes nevertinome.

Mūsų tyrime nedrausmingas VNE vartojimas nekoreliavo ir su paciento amžiumi. Tokie pat rezultatai gauti ir kitose studijose [18, 20, 28, 29], nors kai kuriuose tyrimuose dažniau nedrausmingai VNE vartoja vyresni asmenys, ypač perkopę 65 metus - čia dažnis svyruoja nuo 31,8 iki $50 \%$ [22, 23, 25, 31, 32]. Tokị rezultatą gali lemti didesnis vyresnių asmenų jautrumas VNE šalutiniam poveikiui, gretutinès ligos, politerapija, vyresniems asmenims sunkiau suprasti ir laikytis paskirto gydymo režimo dèl pažinimo sutrikimų ar kitų fizinių sunkumų (pvz., sunku nuryti tabletes ar atidaryti vaistų dėžutes) [16, 23, 33]. Mūsų tyrime VNE vartojimo drausmingumui šie veiksniai įtakos neturejjo. Taip pat gydymo režimo nesilaikymui vyresnių asmenų grupeje įtakos gali turėti ir vaistų ịperkamumas [23, 33], tačiau šio veiksnio mes savo tyrime nevertinome. Kontraversiška išvada pateikta kitose studijose - čia blogiau vaistus vartoja jaunesni pacientai $[7,8,26]$. Manoma, kad prastesnị vaistų vartojimą jaunesniame amžiuje gali lemti geresnis sveikatos būklès vertinimas, greitesnis gyvenimo tempas ir didesnis užimtumas, mažesnis dėmesys kreipiamas ị sveikatos būklę [6, 7]. Amerikiečių apžvalgoje nustatyta, kad prastas VNE vartojimo režimas paauglystëje yra susijęs su jaučiama stigmatizacija ir išsiskyrimu iš kitų bendraamžių [33].

Mūsų tyrimo rezultatai parodè, kad asmenys, nesilaikantys gydymo režimo, dažniau patiria priepuolius. Tokius pat rezultatus gavo airių ir kiti mokslininkai $[8,11,20$, 21, 28]. Manoma, kad dažnesnius priepuolius patiriantiems pacientams sunkiau laikytis gydymo režimo dẻl galimų su priepuoliais susijusių atminties sutrikimų. Lyginant su kitais tyrimais, VNE nedrausmingai vartoja $70 \%$ brazilų, patyrusių priepuolius per paskutinius 6 mènesius (72\% patyrusių priepuolius per paskutines 30 dienų) [8], $41 \%$ anglų, patyrusių priepuolius per paskutinius mėnesius [28], $63 \%$ amerikiečių, patyrusių bent vieną priepuolį pas- kutiniais metais [21]. Mūsų tyrime 80 \% nedrausmingai besigydančių asmenų patyrẻ bent vieną priepuolị paskutiniais metais.

Nustatėme, kad VNE vartojimo režimas su vartojamų VNE skaičiumi nėra susijęs, tačiau priklauso nuo dozių skaičiaus - kuo mažiau kartų per dieną vartoja VNE, tuo prasčiau laikosi paskirto gydymo režimo. Amerikiečiai savo tyrimu patvirtino, kad retesnis VNE dozavimas (prailginto atpalaidavimo VNE vartojimas) nebūtinai pagerina jų vartojimą [34], o praleistos dozès itin padidina priepuolių pasikartojimo riziką [35]. Nedrausmingas VNE vartojimas gali būti susijęs ne su VNE dozių skaičiumi, o su bendra paciento sveikatos būkle, gyvenimo kokybe ir ịsitraukimu į gydymą [34]. Kinai savo tyrime reikšmingo skirtumo tarp monoterapijos ir politerapijos taip pat nenustate, tačiau rado priešingą rezultatą - vartojantys $\geq 3$ kartus per dieną blogiau laikosi gydymo režimo [29]. Vokiečių tyrime (ištirta per 31 tūkstanti pacientų) nustatyta, kad VNE vartojant $\geq 2$ kartus per dieną pablogèja VNE vartojimo drausmingumas [27]. Tai būtų galima susieti su kasdienės asmens rutinos sutrikdymu - dažnesnis vaistų vartojimas apsunkina kasdienę epilepsija sergančių asmenų veiklą, sukelia nepatogumų. O štai Etiopijos mokslininkai nustatè, $k$ ad skyrus vartoti $\geq 3$ vaistus, vaistai dažniau nevartojami [36]. Taip pat kitose studijose nuo 20,9 iki $32 \%$ nedrausmingą vaistų vartojimą lemia didesnis vartojamų VNE skaičius [18, 26]. Tai gali būti susiję su blogesniu VNE toleravimu ir dažniau atsirandančiomis VNE tarpusavio reakcijomis ar šalutiniais reiškiniais $[11,37]$.

Keliuose tyrimuose nustatyta, kad VNE vartojimo drausmingumas nepriklauso nuo ligos trukmès [8, 18, 29]. Mūsų tyrimo rezultatai atitinka kinų [16] ir amerikiečiu [17] gautus rezultatus, kad asmenys, ilgiau sergantys epilepsija, dažniau linkę nesilaikyti VNE vartojimo režimo. Amerikiečių tyrime nustatyta, kad 2/3 pacientų, vartojančių VNE ilgiau nei 5 metus, praleidžia VNE dozes, o praleistų VNE dozių dažnis didejja kiekvienais vèlesniais metais - VNE dozę praleidžia $52 \%$ gydomų vienerius metus, $80 \%$ - gydomų 11 ir daugiau metų [17]. Prastesnị VNE vartojimą galima sieti su ligos remisija. İvairių tyrimų duomenimis, simptomams pagerejus, nuo 8,4 iki $8,5 \%$ respondentų nutraukia VNE vartojimą $[8,36]$. Tai yra gerokai daugiau, nei mūsų tyrime $(2,9 \%)$.

Net 82,4 \% mūsų apklaustų pacientų nurodè, kad dažniausia praleistos VNE dozès priežastis - užmaršumas. Kitų tyrimų rezultatais, ši priežastis svyruoja nuo 32,5 iki $84,1 \%$ [8, 10, 16, 18, 20, 36, 38]. Panašiausius rezultatus gavo norvegai - 84,1\% respondentų nurodè, kad yra pamiršę išgerti VNE ir nesilaikę nurodyto gydymo režimo; tai buvo susiję su depresiška nuotaika, jaunesniu amžiumi, atminties problemomis [38]. Mes savo tyrime nuotaikos ir atminties sutrikimų nevertinome, tačiau nustatėme, kad moterys patikimai dažniau pamiršta išgerti VNE. Subjektyvią nuomonę galejjo lemti didesnis moterų atsakingumas ir sąžiningesnis anketos užpildymas. Norvegų mokslininkų tyrimo duomenimis, patiriama stigma yra susijusi su tuo, kad dažnai pamirštama išgerti VNE, o kasdienis ir ilgalaikis vartojimas yra susijęs su didesne stigmatizacija 
[38]. Galimai tai yra viena iš priežasčių, dèl ko moterys dažniau pamiršta išgerti VNE.

İvairiuose tyrimuose nuo 5,4 iki $70 \%$ respondentų nurodo, kad nesilaiko drausmingo gydymo režimo dèl patiriamų šalutinių reiškinių $[12,13,16,18,26,27,31,38]$. Mūsų tyrime šią priežastị nurodè 7,4 \% apklaustųjų. Toks didelis rezultatų svyravimas priklauso ir nuo vaistų, kuriuos vartoja pacientai, - tyrimuose su dideliu šalutinių reiškinių procentu pacientai vartojo senosios kartos VNE, kurie daug dažniau sukelia šalutinị poveikį. Kaip kitas VNE nevartojimo priežastis pacientai nurodo: neturi VNE $(3,8-12 \%)[16,20,36]$, vaistų skonis ir tabletès dydis (18\% ir $14 \%$ ) [18], tablečių laužymas (12,3\%) [26], negali nusipirkti vaistų $(1,9-21,5 \%)$, blogi paciento ir gydytojo santykiai $(9,5 \%)[13,16,36]$, sunkejjantys ligos simptomai (9\%) [8] ar papildomas vaistų vartojimas dieną $(5,4 \%)$ [26]. Mes savo anketoje šių konkrečių klausimų neuždavėme, o patys pacientai tokių priežasčių nenurodè.

Mūsų tyrime 7 \% apklaustụjų nurodè turintys neigiamą nuomonę apie gydymą VNE. Kituose tyrimuose šis procentas svyruoja nuo 12,8 iki 25,7 [16,36]. JK susirūpinimą dèl ilgalaikio vaistų vartojimo išreiškė $48,7 \%$ apklaustųu (mūsų tyrime - 42 \%), o 19 \% bijo nepageidaujamų reakcijų dèl VNE vartojimo. Trečdalis $(28,1 \%)$ respondentų nurodè, kad tampa nuo vaistu priklausomi (mūsų - $27 \%$ ) [30]. Etiopijos mokslininkai savo tyrime $(\mathrm{n}=292)$ nustate, kad daugiau nei trys ketvirtadaliai $(78,4 \%$ ) pacientų įsitikinę, kad vaistai yra svarbūs kontroliuojant jų ligą (mūsų $93 \%$ ), atitinkamai 44,1\% tirtujų yra labai susirūpinę dèl galimo neigiamo vaistų poveikio (mūsų - $42 \%$ ). Nustatyta, kad nerimaujantys dẻl vartojamų vaistų neigiamo poveikio dažniau nesilaiko paskirto VNE gydymo režimo [36].

Ryšio tarp epilepsijos formos ir miego režimo nenustatėme, tačiau nedrausmingai vartojantys VNE dažniau nesilaiko miego režimo. Amerikiečių apžvalgoje teigiama, kad miego trūkumas yra nepriklausomas epilepsiforminių potencialų aktyvatorius [39]. Kitoje studijoje nustatyta, kad gera miego kokybė yra tiesiogiai susijusi su geresne priepuolių kontrole [19]. VNE poveikis miegui gali skirtis priklausomai nuo vartojamų VNE - gali turèti silpnesnį ar stipresni sedacini poveikị, sukelti mieguistumą dieną, sutrikdyti miego struktūrą, miego būdravimo režimą ir paveikti miego kokybę [40, 41], tačiau paskirto VNE režimo laikymasis pagerina naktinį miegą, sumažina mieguistumą dieną ir taip pagerina miego kokybę [42].

\section{IŠVADOS}

1. Gydymo vaistais nuo epilepsijos laikymosi drausmingumas nepriklauso nuo epilepsijos formos: beveik trečdalis (30 \%) epilepsija sergančių asmenų (29,2 \% židinine ir 31,4 \% - generalizuota) vaistus vartoja nedrausmingai.

2. Dažniausia subjektyvi nedrausmingo vaistų nuo epilepsijos vartojimo priežastis sergančiujų židinine ir ge- neralizuota epilepsija grupėse - užmaršumas, o objektyvios: gyvenimas kaimo vietovejje, dažnesni priepuoliai ir retesnès vaistų nuo epilepsijos dozès.

3. Nors absoliuti dauguma epilepsija sergančių asmenų tiki, kad vaistai nuo epilepsijos pagerina sveikatos būklę, kas trečias respondentas abejoja vaistų nuo epilepsijos efektyvumu, patikimai dažniau - sergantys židinine epilepsija.

4. Gydymo vartojimo drausmingumas priklauso nuo paciento požiūrio ị vaistus nuo epilepsijos - netikintys gydymu pacientai nelinkę laikytis gydytojo nurodymų.

5. Trečdalis respondentų naktị miega mažiau nei 7 valandas, daugiau nei pusė nesilaiko reguliaraus miego režimo. Miego režimo laikymosi drausmingumas sergančiųu židinine ir generalizuota epilepsijomis grupèse nesiskiria.

6. Nesilaikantys miego režimo pacientai nelinkę drausmingai vartoti skiriamų vaistų.

\section{Literatūra}

1. WHO. Epilepsy: a public health imperative [Internet]. Available from: http://www.who.int/mental_health/neurology/ epilepsy/report_2019/en/

2. Sperling MR. The consequences of uncontrolled epilepsy. CNS Spectr 2004; 9(2): 98-109. https://doi.org/10.1017/ S1092852900008464

3. Laxer KD, Trinka E, Hirsch LJ, Cendes F, Langfitt J, Delanty $\mathrm{N}$, et al. The consequences of refractory epilepsy and its treatment. Epilepsy Behav 2014; 37: 59-70. https://doi.org/10.1016/j.yebeh.2014.05.031

4. Fanta T, Azale T, Assefa D, Getachew M. Prevalence and factors associated with perceived stigma among patients with epilepsy in Ethiopia. Psychiatry J 2015; 2015: 627345. https://doi.org/10.1155/2015/627345

5. Group BMJP. Diagnosis and management of the epilepsies in adults and children: summary of updated NICE guidance. BMJ 2012; 344: e1173. https://doi.org/10.1136/bmj.e1173

6. Faught E. Adherence to antiepilepsy drug therapy. Epilepsy Behav 2012; 25(3): 297-302. https://doi.org/10.1016/ j.yebeh.2012.08.027

7. Chapman SCE, Horne R, Eade R, Balestrini S, Rush J, Sisodiya SM. Applying a perceptions and practicalities approach to understanding nonadherence to antiepileptic drugs. Epilepsia 2015; 56(9): 1398-407. https://doi.org/10.1111/ epi.13097

8. Ferrari CMM, de Sousa RMC, Castro LHM. Factors associated with treatment non-adherence in patients with epilepsy in Brazil. Seizure 2013; 22(5): 384-9. https://doi.org/ 10.1016/j.seizure.2013.02.006

9. Malek N, Heath CA, Greene J. A review of medication adherence in people with epilepsy. Acta Neurol Scand 2017; 135(5): 507-15. https://doi.org/10.1111/ane.12703

10. Gurumurthy R, Chanda K, Sarma G. An evaluation of factors affecting adherence to antiepileptic drugs in patients with epilepsy: a cross-sectional study. Singapore Med J 2017; 58(2): 98-102. https://doi.org/10.11622/smedj.2016022

11. Rourke GO, Brien JJO. Identifying the barriers to antiepileptic drug adherence among adults with epilepsy. Seizure 2017; 45: 160-8. https://doi.org/10.1016/j.seizure.2016.12.006

12. Samsonsen C, Reimers A, Bråthen G, Helde G, Brodtkorb E Nonadherence to treatment causing acute hospitalizations in 
people with epilepsy: an observational, prospective study. Epilepsia 2014; 55(11): e125-8. https://doi.org/10.1111/ epi. 12801

13. Getnet A, Woldeyohannes SM, Bekana L, Mekonen T, Fekadu W, Menberu M, et al. Antiepileptic drug nonadherence and its predictors among people with epilepsy. Behav Neurol 2016; 2016: 3189108. https://doi.org/10.1155/2016/ 3189108

14. Nakhutina L, Gonzalez JS, Margolis SA, Spada A, Grant A. Adherence to antiepileptic drugs and beliefs about medication among predominantly ethnic minority patients with epilepsy. Epilepsy Behav 2011; 22(3): 584-6. https://doi.org/ 10.1016/j.yebeh.2011.08.007

15. Hovstadius B, Petersson G. Non-adherence to drug therapy and drug acquisition costs in a national population - a patient-based register study. BMC Health Serv Res 2011; 11: 326. https://doi.org/10.1186/1472-6963-11-326

16. Liu J, Liu Z, Ding H, Yang X. Adherence to treatment and influencing factors in a sample of Chinese epilepsy patients. Epileptic Disord 2013; 15(3): 289-94. https://doi.org/ 10.1684/epd.2013.0588

17. Cramer JA, Glassman M, Rienzi V. The relationship between poor medication compliance and seizures. Epilepsy Behav 2002; 3(4): 338-42. https://doi.org/10.1016/ S1525-5050(02)00037-9

18. Laville F, Montana M, Roux N, Rathelot P, Giorgi R, Vanelle P. Factors limiting adherence to antiepileptic treatmet: a French online patient survey. J Clin Pharm Ther 2018; 43(1): 73-9. https://doi.org/10.1111/jcpt.12615

19. Kataria L, Vaughn BV. Sleep and epilepsy. Sleep Med Clin 2016; 11(1): 25-38. https://doi.org/10.1016/j.jsmc. 2015.10.008

20. Hovinga CA, Asato MR, Manjunath R, Wheless JW, Phelps SJ, Sheth RD, et al. Association of non-adherence to antiepileptic drugs and seizures, quality of life, and productivity: survey of patients with epilepsy and physicians. Epilepsy Behav 2008; 13(2): 316-22. https://doi.org/10.1016/ j.yebeh.2008.03.009

21. Jones RM, Butler JA, Thomas VA, Peveler RC, Prevett M. Adherence to treatment in patients with epilepsy: associations with seizure control and illness beliefs. Seizure 2006; 15(7): 504-8. https://doi.org/10.1016/j.seizure.2006.06.003

22. Faught E, Duh MS, Weiner JR, Guérin A, Cunnington MC. Nonadherence to antiepileptic drugs and increased mortality: findings from the RANSOM Study. Neurology 2008; 71(20): 1572-8. https://doi.org/10.1212/01.wnl. 0000319693.10338.b9

23. Piper K, Richman J, Faught E, Martin R, Funkhouser E, Szaflarski J, et al. Adherence to antiepileptic drugs among diverse older Americans on part D Medicare. Epilepsy Behav 2017; 66: 68-73. https://doi.org/10.1016/j.yebeh. 2016.10.017

24. Manjunath R, Davis KL, Candrilli SD, Ettinger AB. Association of antiepileptic drug nonadherence with risk of seizures in adults with epilepsy. Epilepsy Behav 2009; 14(2): 372-8. https://doi.org/10.1016/j.yebeh.2008.12.006

25. Davis KL, Candrilli SD, Edin HM. Prevalence and cost of nonadherence with antiepileptic drugs in an adult managed care population. Epilepsia 2008; 49(3): 446-54. https://doi.org/10.1111/j.1528-1167.2007.01414.x

26. May TW, Berkenfeld R, Dennig D, Scheid B, Hausfeld H, Walther S, et al. Patients' perspectives on management and barriers of regular antiepileptic drug intake. Epilepsy Behav
2018; 79: 162-8. https://doi.org/10.1016/j.yebeh. 2017.11.039

27. Gollwitzer S, Kostev K, Hagge M, Lang J, Graf W, Hamer HM. Nonadherence to antiepileptic drugs in Germany: a retrospective, population-based study. Neurology 2016; 87(5): 466-72. https://doi.org/10.1212/WNL. 0000000000002791

28. Smithson WH, Hukins D, Buelow JM, Allgar V, Dickson J. Adherence to medicines and self-management of epilepsy: a community-based study. Epilepsy Behav 2013; 26(1): 109-13. https://doi.org/10.1016/j.yebeh.2012.10.021

29. Guo Y, Ding X-Y, Lu R-Y, Shen C-H, Ding Y, Wang S, et al. Depression and anxiety are associated with reduced antiepileptic drug adherence in Chinese patients. Epilepsy Behav 2015; 50: 91-5. https://doi.org/10.1016/j.yebeh. 2015.06.042

30. Chapman SCE, Horne R, Chater A, Hukins D, Smithson WH. Patients' perspectives on antiepileptic medication: relationships between beliefs about medicines and adherence among patients with epilepsy in UK primary care. Epilepsy Behav 2014; 31: 312-20. https://doi.org/10.1016/j.yebeh. 2013.10.016

31. Zeber JE, Copeland LA, Pugh MJV. Variation in antiepileptic drug adherence among older patients with new-onset epilepsy. Ann Pharmacother 2010; 44(12): 1896-904. https://doi.org/10.1345/aph.1P385

32. Ettinger AB, Manjunath R, Candrilli SD, Davis KL. Prevalence and cost of nonadherence to antiepileptic drugs in elderly patients with epilepsy. Epilepsy Behav 2009; 14(2): 324-9. https://doi.org/10.1016/j.yebeh.2008.10.021

33. French JA, Staley BA. AED Treatment through different ages: as our brains change, should our drug choices also? Epilepsy Curr 2012; 12(Suppl 3): 22-7. https://doi.org/10.5698/ 1535-7511-12.4s.22

34. Bautista RED, Rundle-Gonzalez V. Effects of antiepileptic drug characteristics on medication adherence. Epilepsy Behav 2012; 23(4): 437-41. https://doi.org/10.1016/ j.yebeh.2012.02.002

35. Bialer M. Extended-release formulations for the treatment of epilepsy. CNS Drugs 2007; 21(9): 765-74. https://doi.org/ 10.2165/00023210-200721090-00005

36. Niriayo YL, Mamo A, Gidey K, Demoz GT. Medication belief and adherence among patients with epilepsy. Behav Neurol 2019; 2019: 2806341. https://doi.org/10.1155/ 2019/2806341

37. Kanner AM, Balabanov AJ. The use of monotherapy in patients with epilepsy: an appraisal of the new antiepileptic drugs. Curr Neurol Neurosci Rep 2005; 5(4): 322-8. https://doi.org/10.1007/s11910-005-0078-0

38. Henning O, Johannessen Landmark C, Nakken KO, Lossius MI. Nonadherence to treatment regimens in epilepsy from the patient's perspective and predisposing factors: differences between intentional and unintentional lack of adherence. Epilepsia 2019; 60(5): e58-62. https://doi.org/ 10.1111/epi.14734

39. Lanigar S, Bandyopadhyay S. Sleep and epilepsy: a complex interplay. Mo Med 2017; 114(6): 453-7.

40. Jain SV, Glauser TA. Effects of epilepsy treatments on sleep architecture and daytime sleepiness: an evidence-based review of objective sleep metrics. Epilepsia 2014; 55(1): 26-37. https://doi.org/10.1111/epi.12478

41. Legros B, Bazil CW. Effects of antiepileptic drugs on sleep architecture: a pilot study. Sleep Med 2003; 4(1): 51-5. https://doi.org/10.1016/s1389-9457(02)00217-4 
42. Placidi F, Scalise A, Marciani MG, Romigi A, Diomedi M, Gigli GL. Effect of antiepileptic drugs on sleep. Clin Neurophysiol 2000; 111(Suppl 2): S115-9. https://doi.org/ $10.1016 / \mathrm{S} 1388-2457(00) 00411-9$

\section{Streckytè, R. Mameniškienè}

\section{EVALUATION OF SLEEP AND TREATMENT DISCIPLINE IN PEOPLE WITH EPILEPSY}

\section{Summary}

Introduction. Antiepileptic drugs are effective in treating epilepsy and about $70 \%$ of people with epilepsy can be seizure-free however, undisciplined use of antiepileptic drugs is a major cause of treatment failure.

The aim of the study. To study the discipline of sleep and treatment regimen in people with different types of epilepsy and evaluate their determinants.

Methods. A cross-sectional questionnaire-based study of adults with epilepsy who received antiepileptic treatment. Statistical analysis was performed using MS Excel and SPSS 21.0 programs. Statistical significance was defined with a $\mathrm{p}<0.05$.
Results. The study included 100 participants, $65 \%$ had focal epilepsy and $55 \%$ were women. The median age was $37.5 \pm 15.7$, mean epilepsy duration $-9.5 \pm 11$, mean age of epilepsy onset $21.5 \pm 17$ years. It was found that $30 \%$ of participants did not adhere to their treatment regardless of epilepsy type $(p=0.819)$. Nonadherence was associated with living in a rural area $(\mathrm{p}=0.032)$, frequent seizures $(\mathrm{p}=0.033)$, and less frequent medication dosing $(\mathrm{p}=0.032)$, especially in generalized epilepsy group $(p=0.019)$. Sleep regimen did not depend on epilepsy type ( $p>0.05$ ), 35\% of respondents slept less than 7 hours per night, and $53 \%$ did not follow sleep regimen, which was related to treatment indiscipline $(\mathrm{p}=0.027)$.

Conclusions. Nonadherence to the antiepileptic drugs is common among people with epilepsy. The most common subjective reason is forgetfulness, while objective reasons are living in a rural area, frequent seizures, and less frequent dosage of the antiepileptic drug. More than half of people with epilepsy do not follow a regular sleep regimen and tend to disregard treatment regimen.

Keywords: discipline, epilepsy, sleep, regimen, antiepileptic drugs.

Gauta:

Priimta spaudai:

20200909 